\title{
Loving the Many in the One: Augustine and the Love of Finite Goods
}

\section{J. Warren Smith}

Duke Divinity School, Duke University, Durham, NC 27708, USA; wsmith@div.duke.edu; Tel.: 1-919-660-3415

Academic Editor: Peter Iver Kaufman

Received: 18 August 2016; Accepted: 24 October 2016; Published: 18 November 2016

\begin{abstract}
This is an essay in comparative ethics within the Platonist tradition. Although the primary focus is on Augustine's account of rightly ordered love of neighbor in De vera religione, it analyzes Augustine's account of the love of finite goods by comparing it with Plato's grounding of the love of imperfect creatures within an ontological hierarchy in Symposium. Against the backdrop of the critique by modern readers that neither thinker's teleological and hierarchical view of love allows for a real love of particular individuals, this essay will show how for Plato and Augustine alike, the love of the One-the Beautiful, for Plato, and God, for Augustine—conditions all other loves. Augustine's ontological hierarchy of the one eternal God and the many created goods leads him to insist that the love of God, who alone is loved for his own sake, conditions the Christian's love of neighbors whom she loves not for their own sake but for God's. The Platonic ontology of Augustine's theodicy, it will be argued, allows him to explain how use-love is a genuine expression of love for the neighbor in her particularity and yet remains subordinated to one's highest love of God.
\end{abstract}

Keywords: Platonism; the one and the many; Symposium; Augustine of Hippo; uti-frui; love; On True Religion; On Christian Doctrine

\section{Introduction}

The classic Eleatic problem of the one and the many-the question of whether ultimate reality is single or manifold - evolved in Plato's writings from a question about metaphysics and cosmology to one of ethics and the nature of love. The theory of the Forms, especially that of the Form of the Good, holds, as Gerasimos Santas has emphatically expressed it, "a privileged position: it is prior, ethically, epistemologically, and ontologically to everything else in Plato's universe" ([1], p. 247). The Form of the Good enables Plato to explain how within a Heraclitian world of constant flux the many changeable things possess an underlying stable form or nature that allows for moral discourse [2,3]. The early

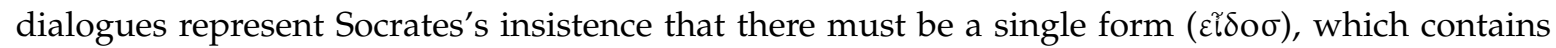
the character common to many things, by which we explain the fundamental unity of the many as instances of one reality [4-6]. By the middle dialogues, the Form of the Good is the One which, as the cause of truth and knowledge and of objects of knowledge (i.e., other Forms), unites all things and so allows knowledge of anything to be useful and beneficial (Rep. 505a). Although the One is not itself a unity, since unity implies an underlying multiplicity ([7], p. 152), knowledge of the Form of the Good provides the unifying principle that allows the city and the soul to exist as a justly ordered and harmonious whole (443d-e). The contemplative intellect's ( $\delta\llcorner\alpha$ vo $\alpha)$ pursuit of the Form of the Good—that Form of Forms by which other Forms become intelligible—is far from a purely theoretical enterprise. It is the quest for the practical wisdom that enables an individual to attain $\varepsilon \dot{u} \delta \alpha \iota \mu$ ovi $\alpha$ both in her general nature as a human being and in her particular role within the city. Socrates' account of the Forms and their particular instantiations (476a) presents Plato's ontology of the one and the many that governs his account not only of politics and ethics but also of love and beauty in the Symposium [8]. The same proves true of Augustine's account of love in On True Religion. 
The Christian distinction between the eternal Creator and finite creatures shares with the Platonic tradition an ontological hierarchy that made the Platonic distinction between the one and the many useful for Augustine's analysis of sin and suffering. This Platonic ontology is key to the theodicy, i.e., a theory of evil, and theory of love Augustine develops in On True Religion both of which prove foundational for his account of a rightly ordered love for God and neighbor, namely that God alone is to be loved for his own sake while the many created goods are loved neither for their own sake nor ours but for God's sake. Such approach is, for Augustine, necessary to avoid idolatry, i.e., loving the creature with the same love one has for the Creator as if God were merely one among many comparable objects of love. Yet their respective views of love based on a hierarchy of being have garnered both Plato and Augustine considerable criticism from their modern interpreters. A hierarchical and teleological ordering of love, so the objection runs, leads one to view all finite goods in purely instrumental terms, as mere means used to attain the final good that is the primary object of love. Through a comparison between Plato's account of love in Symposium and Augustine's in On True Religion and the modern critiques of their respective views, I will argue that Augustine's hierarchical ontology ultimately allows him to reconcile the love of God and neighbor in a way that allows for a true love of neighbor in her particularity.

To be sure, Augustine's primary exposure to a Platonic ontology of the one and the many likely came while in Milan, the center of a Neoplatonist renaissance, where he encountered Marius Victorinus' Latin translations of Plotinus and Porphyry. ${ }^{1}$ Although Augustine had embraced the ideal of philosophical life before his conversion, his understanding of Platonist thought was largely mediated through Christian sources, i.e., the preaching and teaching of Ambrose and Simplicianus. ${ }^{2}$ His serious engagement with Porphyry, however, may not have come until sometime after 400, and even then his knowledge of Plato was through handbooks, such as Cicero's Tusculan Disputations ([16], pp. 8-9, 16-17). I, therefore, focus the comparison on Symposium for heuristic, rather than historical, purposes. First, as the founder of the school, Plato's accounts of the one and the many and his discussions of love, especially in Symposium, set the terms for reflection on those themes in the later tradition. Second, the modern critique of Platonic love, which closely resembles contemporary critiques of Augustine's theory, focuses on Plato's corpus, especially Symposium, rather than Plotinus' Enneads. ${ }^{3}$ The comparison with Symposium, therefore, better serves to highlight features of Augustine's view of love. Third, in Symposium, Plato, like Augustine, grounds his account of love in his ontological hierarchy. Then, through the unfolding of the dialogue that reveals Socrates' relationship with Alcibiades, he dramatically illustrates how the love of the highest good affects the philosopher's love of other human beings, which is precisely the question Augustine is addressing. Before turning to On True Religion, therefore, we should begin with Plato's hierarchy of beauty in Symposium and the similar objections raised against the accompanying vision of love.

\section{Ascending the Ladder of Being}

Socrates' speech in the Symposium recounts his initiation into the mysteries of "E $\varrho \omega \sigma$ by Diotima, who instructs him in the stages of the soul's ascent of the ladder of being. It begins with loving the many, individual, beautiful bodies - the bottom of the ontological hierarchy—gradually making its way upward to knowledge of the single Form of Beauty itself ( $\tau \iota v \grave{\alpha} \dot{\varepsilon} \pi\llcorner\sigma \tau \dot{\eta} \mu \eta \nu \mu i \alpha v \ldots . . \dot{\eta} \dot{\varepsilon} \sigma \tau \iota \kappa \alpha \lambda \mathrm{o} \tilde{u}$

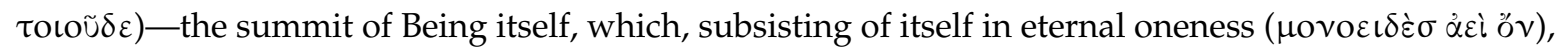
transcends materiality, form, word, and knowledge (Symp. 210d-11b). Like the Form of the Good in

1 While Augustine [9] does not mention Plotinus and Porphyry by name in conf. 7.9.13, speaking only of the libri platonicorum, he does include them, along with Iamblichus, Speusippus, Xenocrates, and Apuleius, in the list of Platonists in de civitate Dei 8.12. See [10].

2 Much of the debate about Ambrose's role has been focused, perhaps unnecessarily, on the dating of his treatises based on his catechetical homilies. See [11-15].

3 Although Plotinus does not lack a political philosophy (see [17]), his discussion of love and beauty (e.g., Enneads I.6, VI.7 and VI.9) focuses on the One's love of itself or the soul's ascent to the One rather than on love between people. See [18]. 
Republic, the Beautiful is the cause of beauty in all that is beautiful. In the many, the initiate recognizes one beauty common to all bodies. From this recognition of the common beauty, which transcends its instantiations in the many particular bodies, the intellect ascends the ontological ladder, grasping

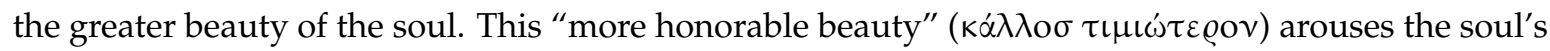
desire for that discourse which yields the "golden harvest" of philosophy, i.e., the knowledge of the Beautiful, and ennobles and beautifies one's character (210b8).

Although the problem of the one and the many is not the primary subject of the Symposium, Plato's portrayal of the soul's erotic quest for wholeness and healing-as seen in Aristophanes' speech-begins with the assumption that the Beautiful is the cause of है $\varrho \omega \sigma$ which propels the soul toward union with Beauty itself. Particularly interesting is how Plato depicts the transformative effect of the soul's mystical vision of the single form of Beauty. The ascending soul is no longer focused on a single, beautiful object but her loving gaze is cast broadly (210d). Once it has beheld Beauty itself, the soul's attitude toward physically beautiful objects is profoundly changed from one of passionate longing to indifference, if not outright disdain. The philosophical life-the purest and highest expression of है $\rho \omega \sigma$ - which seeks the vision of the single and highest form of Beauty liberates the soul from bondage to base, sensual loves. Now the soul is no longer seduced by "the charm of gold, of dress, of comely boys or lads just ripening to manhood" (211d3-4). The one Beauty, which is the standard by which the soul distinguishes the truly virtuous souls from those who have only the semblance of virtue (212a), conditions the soul's love of the many particular goods. The absolute loveliness of Being itself causes the soul to look upon the many instances of beauty as "of little or no importance" (210b). Plato's explicit inclusion of handsome young men in the list of things the initiate will no longer fancy provides an explanation for Alcibiades' complaint that he cannot seduce Socrates. To the distinguished guests at Agathon's drinking party, Alcibiades declares, "He [i.e., Socrates] considers all these possessions [e.g., physical beauty, honor, wealth] beneath contempt, and that is exactly how he considers all of us as well" (216e). Socrates seems no longer to love the handsome Alcibiades.

Such passages have prompted Gregory Vlastos to raise the question of whether the logic of Diotima's account of the soul's ascent up the heavenly ladder is not, in fact, initiation into a solipsistic life of contemplation. Does Platonic love turn out to be a "pleasure-love" or "utility-love" for the other who serves our needs and interests rather than that noble love which desires the other's good for her own sake?" Plato's tendency toward "utility-love" can be found in an early dialogue, the Lysis [20], where Socrates declares, "So if you become wise, my boy, everyone will love you and all will be your kin—for you will be useful and good—otherwise no one will love you" (Lys. 210d1-3). This does not necessarily mean that $A$ is loved by $B$ because $A$ is useful to $B$ (since, for example, A might be loved by $B$ because he is useful to $C$ and $D$ ). Socrates' view of love, however, does not satisfy Aristotle's definition of loving the other for his own sake, which Vlastos takes to be normative ([19], p. 141). The philosopher's love is, for Plato, determined by his ontological hierarchy. The extent of one's love should be proportionate to the object's degree of being and beauty. The proper object of love

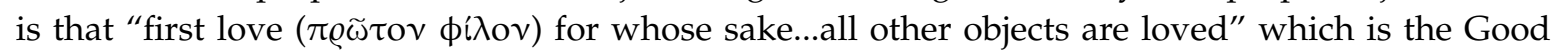
(Lys. 219d-220b). Plato builds upon this theme in the Symposium. Not only is the Beautiful the cause of our love of others insofar as we love them because they bear the image of the Beautiful, but, according to Vlastos, the vision of the Beautiful is "the peak achievement for which all lesser loves are to be 'used as steps' (211c3)." People are loved, not for themselves, but as means of ascending to the Beautiful which "is the one [good] farthest removed from affection for concrete human beings" ([19], p. 161).

Vlastos' critique of Plato's utilitarian love of others finds a striking parallel to many contemporary critiques of Augustine's uti-frui distinction in De doctrina christiana [21]. At the beginning of book I, he distinguishes between things that are to be enjoyed (frui), in which we find happiness, and the

4 Aristotle, EE 1236a16-b27 and EN 8.3-5 1156a6; Gregory Vlastos takes Aristotle's view of love as the standard by which he assesses Plato's. See [19]. 
things that are to be used (uti) to assists the pursuit of the things that are in themselves the source of happiness (1.7). The former are loved for their own sake; the latter are simply means to achieve what we love. Yet unhappiness comes when the two are confused and we are diverted from attaining what should be loved for its own sake by treating as objects of love-ends in themselves-those things that are not ends in themselves (1.8). In the present life, we are travelers seeking to return to our homeland, God, and must use the world to reach our destination rather than think of it as our destination (1.9). Since human beings are rational creatures made in the image of God and thus are special things set apart from other things in the world, Augustine wonders whether they are things to be enjoyed, or used or both (1.39-40). Since finite and imperfect creatures, which are made for fellowship with the infinite and perfect God, cannot find happiness in themselves or other creatures (1.40), Augustine concludes, the love of neighbor and self are conditioned entirely by the love of God (1.43). God alone ought to be enjoyed (frui) while creatures ought to be used (uti) to achieve what one loves. The logic of the distinction rests upon the ontological framework of his eudaimonist ethic. God, as the eternal Good, is the summum bonum and should alone be enjoyed and loved for his own sake. In this enjoyment, rational creatures find their greatest fulfillment. Ultimately, Augustine incorporates the love of neighbor into the ontological structure of his eudaimonism: one loves/enjoys one's neighbor, not in herself (in se), but in God or for God's sake (propter Deum) (1.59-60 and 76). Although in early texts, like Soliloquies, On the Blessed Life and On Free Choice of the Will, Augustine already distinguished between right use and wrong use; in de doctrina, usus is presented as "a form of possession" that implies merely an instrumental relationship with creatures ([22], p. 376). As a result, Augustine's argument has been widely misinterpreted to imply "that love for neighbor should be regarded as an instrumental pursuit by which one intends to attain the beatitude of an immediate love for God..." Consequently, the neighbor is not treated as an end in herself but merely a means "in a frankly exploitive sense." ([22], p. 361). To love the neighbor for the sake of another, if it is not grossly exploitative, at least fails to be a genuine form of love since it is entirely derivative and lacks regard for the particular qualities of the individual neighbor. ${ }^{5}$ Because for Augustine everyone must be viewed as a neighbor, Hannah Arendt concludes, the Christian "loves his neighbor in sublime indifference regardless of what or who he [i.e., the neighbor] is" ([29], p. 42). Consequently, the neighbor is "completely forgotten" and "has ceased to be anything" individually having identity only within a community ([29], p. 109). Augustine's "teleological subordination" of the love of neighbor to a love of God within his eudaimonist ethic "does not really deserve the name of love" since it does not love the neighbor for her own sake. ${ }^{6}$ Such interpretations miss Augustine's point, O'Donovan claims, ${ }^{7}$ and "... [their] very popularity may obscure the experimental and finally inconclusive character of its solution to the problem of the order of love" ([31], p. 26).

O'Donovan has sought to correct this misreading by analyzing the evolution of $u t i$ and frui within Augustine's corpus. There are, however, gaps in his genealogy that need to be reconsidered, specifically regarding the significance of De vera religione. O'Donovan recognizes its critical role in preparing the way for De doctrina christiana by insisting that loving one's enemies is a way of using them to train oneself in patience. For the first time, "use" is spoken of as a form of love. But Augustine seems merely to have juxtaposed the love of neighbor to rather than integrated it with the ontology of his eudaimonism. In other words, his concern is that Augustine does not establish why, given that God alone is intrinsically worthy of love and alone can be the source of happiness, one should love one's

5 For Anders Nygren, it is the neighbor's nature-as it may become in the resurrection - that is the object of love, not the neighbor "in his concrete situation." See [23]. For contemporary variations of this critique, see Lee [24,25]; For contemporary defenses of Augustine on this point, see [24-28].

6 To regard something as a "means" or "instrument" is, Adams says, to value it, not love it. Thus, he does not love his car, but merely values it as a means to get from one place to another [30].

7 The Problem of Self-Love in St. Augustine. [31], sees the uti-frui distinction as a hypothesis that Augustine put forward only to abandon after books I of De doctrina; "The only positive love that remains is that by which a man pursues his final goal, his finis bonorum." 
neighbor. The second half of the love commandment thus "still lacks a satisfactory formal relationship to the ontology of Neoplatonic eudaimonism" ([22], p. 379). Consequently, O'Donovan concludes his appraisal of On True Religion, "Since the object of love is infinite and affords no scope for jealous rivalry, there is no reason why one should not love one's neighbor as one loves oneself, by promoting his access to the supreme good. It is a common enough argument with Augustine, and it fails to satisfy because it does not really address the question of what place there is for a neighbor in the ontology of eudaimonism." ([22], p. 380). It is this conclusion that needs to be reexamined. In what follows, I will argue that On True Religion marks a development in Augustine's thought that expands the ontological basis of his theodicy beyond a focus solely on the contrast between eternal/infinite goods and temporal/finite goods. Accordingly, Augustine's theodicy provides the ontological foundation for his account of the love of neighbor as usus in De doctrina christiana. Moreover, the ontology of On True Religion allows us to see how loving the neighbor in God, far from devaluing the neighbor, in fact allows the Christian fully and rightly to love one's neighbor in all her creaturely particularity.

\section{Augustine's Ontological Foundation for Love}

In On True Religion, written around 390 before his ordination, ${ }^{8}$ Augustine argues for the superiority of Catholic Christianity over Manichaeism by showing the fundamental incoherence of the dualistic Manichean universe, which lacks a principle of unity that is the common source of all things. In the opening sentence, Augustine puts forth the ontology that governs the work: "Every route to the good and happy life is contained in the true religion by which the one God [unus Deus] is worshiped and recognized by the purest piety to be the source [principium] of all nature from whom the universe derives its existence, its perfection and its coherence [continetur]" (vera rel. 1.1) [32]. On this exact point he sums up his argument at the treatise's conclusion, "So you see, I worship the one God, the one Source [principium] of all, and [his] Wisdom by whom the wise soul is wise, and [his] Gift by whom the blessed are blessed" (55.112). The evil of human suffering, therefore, should be seen as the direct consequence of our failure to worship the One True God. Living in a world of many goods but lacking a principle of unity to order our desires, we find that the many created goods become burdensome to the soul and thus the source of unhappiness. The misery lies in our conflicted loves that pull us toward mutually exclusive ends and turn us from the One who alone is the source of happiness, God.

Having said that the evil in sin lies not in the bodily object itself but in the way it is loved (20.40), Augustine explains how sin and its intrinsic punishment become the "vanity of the vain" (vanitas vanitantium) from Ecclesiastes $1: 2^{9}$ by focusing on the notion of abundance in Ecc. 1:3, "What abundance [abundantia] is there for a man in all his toil, with which he toils under the sun?" (21.41). To the vain person, the beauty of the many material goods is vain, i.e., futile, because it does not provide happiness. The problem is that the beautiful bodily objects are many; they are too numerous for the individual to love and enjoy each in its particularity. Augustine explains, "The manifold variety of temporal species has through the bodily senses diverted fallen man from the unity of God and has multiplied his emotional responses with the variety of their changing forms. Thus has been produced $a$ toilsome abundance [abundantia laboriosa] and, if one may say so, a plentiful poverty [copiosa egestas], while one thing follows another and nothing remains with him," (21.41). The burdensome abundance is the consequence of what Augustine will later in Confessions describe as a problem of distention (distentio)

8 Retractiones gives a chronicle of Augustine's writings. De vera religone was written after De magistro and before De utilitate credendi, which was written after his ordination (retr. I.13.1-14.1).

9 Michael Fiedrowicz and Edmund Hill comment in the notes to their translation that Augustine's use of the genitive plural participle vanitantium, rather than the standard noun vanitatum, does not appear in variants of the Septuagint (On Christian Belief, [32] 55n85). 
of the mind that reaches backwards through recollection of the past and forwards toward the future through anticipation. ${ }^{10}$

Augustine's description of the mind's time-consciousness as distentio is not simply a psychological account of time. It is an existential account of the problematic nature of our fragmented existence. It is the problem of becoming: we, and all creatures we love and desire, are ever in process of changing. Inherent to that process of becoming is loss. Although Augustine does not employ the term distentio in De vera religione, his description is the same in all but name, "...for the beauty of bodily things is rushed on in successive order [ordinem successionis]. Such beauty, therefore, is the least [extrema] because it is not possible to have all things simultaneously; but some things give way and others succeed them completing the number of temporal forms of beauty into one single beauty," (21.41). This is the distention of desire stretched by the vast variety and abundance of creaturely goods. Ecclesiastes, for Augustine, characterizes the condition of fallen humanity in terms of both time and abundance. The vanity of human labors is that we toil for goods that are not permanent. The fruit of our efforts is quickly lost and must be replaced by yet further toil. When Ecclesiastes asks, "What abundance is there for a man in all his toil?" the obvious answer to this rhetorical question would seem to be, "None." Since the fruit of our labors is transitory, the end is loss. There is no abundance. Surprisingly, however, Augustine answers the question differently. Precisely because we labor for transitory goods that ever need replacing there is an abundance of goods for which we labor, an abundance of goods that we desire. Yet such an abundance becomes, not the source of ease and happiness, but a burden that produces misery. The distention in time produces a distention of desire. Our experience of the cycle of gain and loss that is the distention of time is accompanied by an expansion or distention of our desire to replace what is passing away. The distention of desire is the source of misery, for Augustine, because we equate that one eternal Good that is to be enjoyed as the source of true eudaimonia with the many transitory goods that are merely to be used to attain that one true end. Such confusion occurs when there is no governing principle to order our desires rightly. On the one hand, we seek enjoyment in many goods that are more numerous than we are able to enjoy and so are miserable because we are unable to find enjoyment in any. On the other hand, we are miserable because we are not able rightly to value the transitory goods whose passing is the source of grief. Our abundance is toilsome (abundantia laboriosa) because all the transitory goods that we possess, for however brief a time, require our continual labor to attain, preserve, protect, and replace. Yet because these many goods are neither eternal nor supremely good-as God is—our toilsome abundance turns out to be a plentiful poverty (copiosa egestas) (21.41). ${ }^{11}$ For the abundance of the transitory goods we have acquired leaves us impoverished, lacking what we need for true happiness. We are, to use an anachronistic analogy, as poor as a Southern widow whose only possession is a fortune in Confederate currency.

In Augustine's account of true religion as the enjoyment of the One God and of suffering as distended desire for the many created goods, we see a development of his theodicy. In earlier works, Augustine focused entirely upon the ontological problem of Being and becoming, i.e., loving the transitory rather than the eternal. Now in De vera religione, his theodicy expands to include the concomitant problem of the One and the many. That is, the abundance of God's many created goods-not just their transitory nature-is itself a cause of the distention of desire if we see our happiness as dependent upon enjoying the many goods.

There is a secondary consequence of trying to enjoy the many created goods as ends in themselves, namely we fail to see the good proper to their individual natures or appreciate their true beauty as parts within the beauty of God's economy of creation and salvation. Although each individual creature

10 Conf. XI.xxvi.33 and xxviii.38. The fundamental problem with distentio animi, James Wetzel argues, is that the mind's attempt to control and organize time fails because the mind cannot encompass itself. The result is (Conf. XI.xxix.39) that Augustine's soul is torn apart; the only solution is for the self to find unity in God's love. See [33].

11 Edmund Hill provides the especially felicitous and poignant translation of copiosa egestas as "plentiful poverty" (On Christian Belief, [32] p. 55). 
reflects the goodness of the Creator, Augustine implicitly distinguishes between the reflective beauty of the particular creature, the reflective beauty of the whole of creation, and the intrinsic beauty of the Creator. A particular individual thing is never truly beautiful in itself. The color black, for instance, by itself is ugly. United with other colors in a painting, however, black becomes beautiful because it participates in the beauty of the whole (40.76). In failing to rise above the beauty apprehended by the senses and so focusing on the many particular creatures, humanity grasps, not the whole, but only the part or a succession of parts. Indeed, the beauty of the part achieves greater beauty when the succession of parts culminates in the beauty of the whole. To illustrate the relationship of the fragmentary beauty of the part to the greater beauty of the whole, Augustine introduces an analogy that he will develop in Confessions to explain the distension of time: the syllable within a line of poetry. It is not any single syllable, but the succession of the syllables, that gives the verse its beauty. Indeed, the beauty of the whole poem cannot be actualized without the succession of syllables. The beauty of the poem is the artistry that governs and provides unity and structure to the whole poem, juxtaposing certain syllables at certain moments to convey the overall effect of sound or meaning. Some must pass away so that others may be spoken (22.42). Thus the transitory nature of many creatures is not evil, but contributes to the perfection of the divine "poem" of creation. After the sound of the final stanza passes away into silence, the intellect retains in memory its comprehension of the craftsmanship of the composition. Fallen humanity, in trying to enjoy an individual as good in and of itself, is as ludicrous as a person who would love only a single syllable in a poem or single chord of a song and want to listen to it over and over-all the while being uninterested in discovering the beauty of the whole poem or song. Even worse than ignoring the beauty of the whole poem or song, they are oblivious to the poet's artistry that is truly beautiful. In focusing only on the single syllable, ironically, they miss, not only the greater beauty of the poet's artistry, but also the true beauty of syllable or chord.

The alternative to our toilsome abundance and the accompanying distention of desire Augustine finds in Psalm 46:10, "Be still and know that I am the Lord." The "stillness" God commands is not inactivity but contemplative stillness (otium cogitationis) in which the soul transcends time and place. That is, God's command, "Be still," is an invitation to freedom from bondage to the hardships of the transitory nature characteristic of extension in time and place. A soul dominated by the habits of bodies (consuetudo corporum) is a soul attached to transitory goods and so is subject to the burden of many goods and many desires. He writes,

"For these swollen and fleeting phantasms [phantasmata tumoris] [proper to time and place] do not allow us to see the constant unity. Places offer us things to love, time snatches away things we do love and leave behind in the soul a swelling throng of phantasms (turbas phatasmatum) to incite its greed for one thing after another. Thus the soul that is seeking to hold the desired objects by which it is held is made restless and wretched."12

The phantasmata here are not simply impressions of many things left on the mind by the senses; they are impressions that arouse in our imagination desires of an exaggerated magnitude. The soul becomes possessed by the desire to possess more and more. Its unfulfilled cupidity agitates the soul relentlessly driving it ever seeking to hold what it desires. Pulled in many directions by many desires the fallen soul does not rest in the One who orders the many in the unity of creation. By contrast, the soul that obeys God's command to be still understands how the cross-bearing disciple of Christ can find "his yoke easy and his burden light" (Mt 11:30). The yoke of Christ is contemplative stillness that sets one's heart upon the One. Christ's yoke-though a sign of our subjection to God as sons and daughters of God-stands in contrast to the burdensome yoke of slavery under which "the friends of this world" futilely toil. The Christian's yoke is easy because it is freedom from the frenetic quest of avarice and the hard labor that inescapably accompanies the pursuit of many goods. Indeed the

12 De vera religione 35.65. Hill [32] may be correct in translating phantasmata as "fancies" rather than "phantasms". 
"friends of this world" are subject to toil wrought by their disordered cupidity motivated by a fear of loss; they "are so afraid of being torn from [the world's] embrace that they find nothing more laborious than not toiling away at hard labor" (35.65). The sons of God, in a sense, attain the many goods but without toil. For in setting their hearts upon the One who is the source of all things they have subjected the many to their single love of God. In the single-minded love of God, the sons of God love the many created goods in God. In other words, they experience the world not as the fragmentation of ever multiplying phantasmata but as a cohering unity in the One who is its source.

\section{Redeemed from Distention: Knowing the One God}

The One God of true religion does not redeem us from the burdensome life among the many by absorbing all creatures into Himself. Rather, God as the one source of all goods makes himself the unifying principle of human love so that we are able to love many creatures in the one Creator. De vera religione narrates redemption and liberation as God's restoration of unity and harmony to the soul and to material creation-a harmony and unity that was lost when humanity began to seek enjoyment in material bodies rather than in God. Augustine presents this Christian vision of salvation with its focus on the restoration of unity to creation as diametrically opposed to that of the Manichees. Within the Manichaean dualistic cosmology, human existence is inherently conflicted. There is no single source of our nature and our existence. We are composed of two natures derived from two contradictory and ultimately irreconcilable gods or principles. ${ }^{13}$ Since there is no first principle, no principle of unity, there is no possibility of peace in the Manichaean salvation. The conflict between the warring natures is not brought to an end through reconciliation. At best, the god of the Manichees counters the power of the dark principle by admixture (commixtio), i.e., mingling the light with the element of darkness to dilute its power. By contrast, Augustine envisions redemption as a restoration of the unity and peace inherent in a creation that derives its life from the one true God. For life itself entails unity: "There is no life that is not from God, because God is supreme life and is himself the fountain of life" (11.21). Our bodies, though they have an inherent instability since they were created from nothing and are not themselves the source of their own existence, exist because they have a certain harmony among their parts. Existence is nothing other than the shape or form given by the Creator. Without the particular form that makes a thing what it is, it would have no existence; it would be nothing. Since a corporeal being is not simple but comprised of parts, the form of a thing is the configuration of its many parts, its manifold substance. The Christian's happiness is linked to the knowledge of her own form and its relationship to the form of other creatures. This knowledge comes in God's self-disclosure in the Incarnation of the Word.

The art that gives beauty to creation as a whole is what Augustine calls the "primordial formulae" or patterns. ${ }^{14}$ The beauty of creation's artistry lies in the beauty of divine providence or divine Wisdom which itself is above the primal formulae. ${ }^{15}$ This pattern is the source of primordial order that gave

13 Without mentioning the Manichees by name, Augustine epitomizes their teachings, "...[they] maintain that there are two natures or substances, each with its prime source, which are constantly at war with each other... Two souls in one body, one from God, which is by nature what he is, the other from the race of darkness, which God neither begot nor made nor produced nor discarded, but which had its own life, its own territory, its own brood and animated beings and finally its own kingdom and unbegotten primary source" (vera rel. 9.16). For Manichaean cosmology, see [34].

14 Augustine speaks cryptically of the beauty of corporeal things as manifesting "vestigia primorum numerorum" (40.75), which Fiedrowicz and Hill render "the primordial formulae" (On Christian Belief, p.80n144), and John Burleigh more literally as "the primal numbers" [35]. Although he likely is employing the mathematical language used in certain philosophical schools to speak about the ordering of the cosmos, Augustine does not specify. The term "primorum numerorum" simply suggest God's logical, mathematical ordering of various natures in creation. For in his analysis of the "unchanging law of numbers", he explains that no creature, knowingly or otherwise, "does not bring to bear something well numbered and regulated of its kind...[but] acts within the innermost limits of its nature, which are regulated by that unchanging law of number." (42.79).

15 Although he speaks only of divine providence in 22.42 , he equates divina providentia with sapientia Dei in 40.75 . By going on to say of the primi numeri are those "in quibus sapientiae Dei non est numerus", Augustine is following both the Biblical and Neo-Platonic view that God is cannot be numbered as one thing among many others. For number implies form and limit which are absent in God. 
peace to the cosmos. Unlike the Manichaean creation that is inherently conflicted, creation, in the Christian narrative, exists originally in a state of order and peace. For peace lies in the harmony within the parts of our created form. Augustine goes so far as to say that the peace, of which the body is inherently capable, mirrors the peace of God's own form. He writes, "The body gets a kind of peace from its shape, without which it would certainly be nothing. He [i.e., God], therefore, is also the artificer of the body, from whom is all peace and who is uncreated form, and of all forms is perfect form [formosissima]" (11.21). Through the Incarnation of the Word, who is the Father's wisdom, God reveals to human beings the primordial formulae by which we recognize the true nature or form of particular creatures. The Word that is the source of all form is also the source of unity that holds all creation together. The form the Word gives to anything determines its nature and distinguishes it from other species. Form is the principle of differentiation. Yet implicit in the form, the nature of the species, is the principle of unity that determines one species' relationship to the other members of the whole. No species exists in isolation, but always in relationship to other species. Every species' nature or form, therefore, includes both its distinctive features and its connection, either direct or indirect, to all other species of the created order and to its Creator. To use an anachronistic analogy, the form is like a piece of a jigsaw puzzle, which has its own distinctive configuration. Its distinctiveness, contour, and color, however, do not exist in isolation, but are determined by its place within the whole puzzle.

By ascribing perfect form to God, Augustine makes a radical departure from the Neo-Platonist tradition. For Plotinus, the realm of Being is the realm of the forms, the paradeigmata on which the world is modeled. The forms give to material objects their nature and identity. It is form that turns amorphous matter into something. Without form, matter is no thing. Form is the source of a thing's discrete existence. God, whom Plotinus calls the One and the First Principle, however, is simple. It is the unconditioned condition of all things. The forms are generated by Intellect (Nous), the Second Principle, in its contemplation of the One. Intellect contemplates the simple beauty of the One in multiplicity. The One has no form or shape; if it did, what it is would be conditioned by that form. The form of its nature would be prior to the One and would be the cause of the One itself. In that case the One would not be the First Principle. Plotinus, therefore, would never say that God is formosissima. Augustine, however, does. His point is not that God is one thing among other things, one form of being among other forms. Rather, formosissima is Augustine's way of expressing conceptually the meaning of Psalm 36:9: "for with you is the fountain of life." God is one and immaterial and so not composed of parts. Yet in God's oneness, there is an abundance and fecundity to his creative imagination and will that gives form to all things. The One is the source of the many and so holds the many in unity, harmony, and peace. Not surprisingly, in Augustine's account of the New Man's ascent to God (Eph. 4:24), the penultimate stage before entry into the rest and bliss of justice, is the restoration of the imago Dei, i.e., acquisition of one's perfect form in conformity with God's perfection. This is eternal life: perfect being in perfect form (26.49).

Having received its new form from the Word-and implicitly the Holy Spirit-who is the One and whose form is the source of unity for the whole of creation, the rational soul is not subject to but exerts dominion over the body (12.25). The soul's absolute dominion of the body here is not the soul-body relationship in the present age, but as in the resurrection when the saints shall be akin to the angelic nature which is free from death, sexual passion, and other bodily appetites. Augustine here employs, as Ambrose before him ([15], pp. 29-33), a Plotinian conception of the soul's mediatorial role in governing the body.

Epistemologically, therefore, the Word, who is consubstantial with the One, in himself provides the knowledge of the One necessary to distinguish between the verisimilitude of unity in many creatures and the true Unity of God. Augustine's concern for the epistemological significance of the Word is revealed in his shift to speaking of the Word as Truth (Veritas). "This is the Truth which shows him [i.e., God] as he is, which is why it [i.e., the Truth] is appropriately called his Word and Light... So just as truth is the form of things being true... it is the form [forma] of all things that are, who is the supreme Likeness of the Beginning and is Truth, because it is without any unlikeness at 
all" (36.66). That is, Christ is the Truth because as the Principium Christ not only gives form to all individual creatures but in his architectonic Wisdom is the meta-form that provides knowledge of the right relationship of the many parts to the whole. For only in knowing the relationship of a particular creature to the whole of creation is one able to know that the creature is not to be, and indeed cannot be, enjoyed in itself. Only in seeing the relationship of the particular good to the whole-its place in the matrix of interrelations that orders creation-is one able to value and use it rightly in one's service and enjoyment of God. Because the Son is perfectly like the Father and so contains the forms of all things that come from the Divine fountain, he is Truth. For in him, the perfect and eternal form is the key to understanding the true, unchanging nature of the world as God willed it. Even more, as the inner light the Son imparts understanding of form by which we are able to see the true nature of individual species and their proper place in God's creation. Commenting on Jesus' exhortation to the disciples to "walk while we have the light of day" (Jn 12:35), Augustine explains that the daylight is none other than Christ himself who is "the light that enlightens every man" (Jn 1:9). The light that was coming into the world did not illuminate the eyes of the head but those of a believer's reason by which he is able to rise from where he has fallen (42.79).

The understanding of truth that Christ the Light imparts to the soul is not merely cognitive, but also affective. Not only do we see that God alone is to be enjoyed, but we also see how to love the many creatures rightly. Because Christ himself is the inner light that abides in and illuminates the mind, our intellect is illuminated by the very Principle of unity that orders the many goods in creation. Loving the many creatures not as ends in themselves to be enjoyed but as means of serving God and as parts of the whole that reflects God's beauty, we are freed from the distention of desire that takes the form of greed or covetousness (cupiditas). ${ }^{16}$ In the light of the One, our intellect and our appetites are no longer deceived by the beauty of the part. We are no longer made anxious in the midst of our abundance because we dread the loss of quickly fleeting goods in which we have sought enjoyment. In discovering the One thing that is necessary we are freed from the fear inherent to the cycle of gain and loss-no longer continually grasping for new goods that we hope in vain will sustain our lives and give us security. Rather, for Augustine, we are content in the midst of material abundance because we find our delight in the abundance of the One in whom are all things. It is this theological rendering of the ontology of the One and the Many in On True Religion with its account of the disordered desire of sin and Christ's redemptive work as re-former and healer of distention that provides the grammar for understanding the development of Augustine's uti-frui distinction and his account of the proper love of neighbor.

\section{Beyond Mere Instrumentality}

Although Augustine employs the language of usus and fruitio in De vera religione to contrast the love of God and the love of neighbor, he does not explicitly pair them as antitheses as he does in De doctrina christiana. Nevertheless, he employs the logic of instrumental relations to address the same fundamental question: What is the proper nature of the love we have for our fellow creatures that is not idolatrous enjoyment (frui)? Christians cannot love the finite, contingent creature as if it were their highest good. Creatures are not ends in themselves but are God's instruments to which he assigned different roles within the drama ordained by Providence. ${ }^{17}$ Proper love of neighbors, therefore, entails for Augustine treating or using them according to their place in the design of Providence. For example, heretics in the Church are a benefit (beneficium) of Providence intended to reveal those who are tried and faithful (probati) (cf. 1 Cor. 11:19). We should, therefore, "make use" (utamur), Augustine says,

16 Although Augustine, quoting the baptismal formula in Gal. 3:28, "in Christ there is neither male nor female," allows that women need not be subjected to cupiditas, he speaks of virtuous women as conquering "female pleasures" (femineas voluptates) by become manly (virile), vera rel. 41.78 .

17 Augustine picks up the theme of instrumentality of the parts within Providence's ordering of the whole of salvation history in De doctrina christiana 1.85 . 
of the heretics as a beneficium of Providence given to prod the Church to seek an understanding of the truth. Even if we cannot bring the heretics back to salvation, we love them as God's instrument for instructing us in right doctrine (8.15). The same is true of relations with friends and enemies. The former we "use" to learn gratitude and the latter we "use" to learn patience (47.91). ${ }^{18}$

The idea of "using" a friend or an enemy to advance in virtue sounds narcissistic and seems to miss the mark of Christian love. After all, one can imagine an ostensibly benevolent act that entails no real regard for the person benefited but that simply makes use of another person's need in order to make oneself more virtuous. ${ }^{19}$ Here Augustine seems vulnerable to Arendt's critique: Augustine's love of the enemy is not real love but merely a "sublime indifference" to the enemy made possible because the Christian knows the enemy cannot deprive her of what she loves most-God ([29], p. 43). Uti-love, however, does not treat the neighbor as a mere instrument-a stepladder to ascend to God-that is dispensed with once one has attained one's end ([37], p. 171). Rather as Raymond Canning has showed, although the love of neighbor is a step or gradus to the love of God, gradus corresponds with a level being which has a corresponding action..$^{20}$ Thus the love of neighbor and self, who occupy the same gradus, holds the same penultimate status subordinate only to the love of God. The neighbor is not left behind as the saint progressively rises in her love of God but is enjoyed in God in whom self and neighbor find mutual blessedness. For, as Augustine earlier established, the end of a Christian's love of the neighbor, especially an enemy, is reconciliation or salvation. ${ }^{21}$ When Augustine speaks of using one's enemy to learn patience, he adopts what at first glance appears to be a Stoic posture: since the reconciliation and redemption of the enemy is ultimately beyond my control, one focuses on what is within one's power, namely, cultivating the virtue of patience. This reading, however, does not take into account Augustine's adaptation of the Golden Rule to qualify the proper love of neighbor or what he calls "the rule of love" (regula dilectionis): "as one wills to provide good things to oneself one also wills it for the other and as one does not wish bad things to happen to oneself one does not wish them for others" (46.87). The enemy's redemption is necessarily the ultimate goal of love for the enemy. That is, if loving one's neighbor as oneself means willing for one's enemy the good things one wills for oneself, then necessarily such love entails desiring for one's enemy the very blessing of salvation one desires for oneself (46.87). Because desire for the Common Good regulates the love of self and neighbor in the Golden Rule, there is no egoist drive to surpass one's neighbor in virtue ([26], pp. 228-29). There is no place for the zero-sum game typical of the Homeric honor-shame system; there is only the celebration of virtue regardless of who attains it. Moreover, patience towards one's enemy is both how one expresses love for God (by obeying the command to love our enemies) and how one learns to love others as God patiently loves us, who by sin made ourselves enemies of God. As an imitation of God's love, our patience is itself a participation in God's love. By imitating God's love towards the enemy, the Christian becomes God's instrument in Providence's plan for the enemy's redemption. Indeed, uti-love of the neighbor is an imitation of how God uses people to attain for them the highest good he wills for them. ${ }^{22}$ We do not care for the other, therefore, as a master cares for his slave; that is, for no greater purpose than that the slave remains healthy in order to be productive and useful to the master. ${ }^{23}$

18 This passage is the first time Augustine applies usus to people. Moreover, it marks a shift away from what O'Donovan calls the "predominantly instrumental sense" with which Augustine uses it to speak of other temporal things. See O'Donovan $[22,26]$.

19 A classic instance of pseudo-benevolence that "uses" the recipient for self-aggrandizement is Katerina Ivanovna's offer to marry Dmitri Karamozov in order save him from himself. Dmitri sees the real object of her love, "She loves her own virtue, not me." [36].

20 See De mor. eccl. 1,26.50 and De mus. 6.14.46 in Raymond Canning [26].

21 De mor. eccl. 26. True love of the enemy is willing that he come to know the perfect blessedness of God's love. See [38,39].

22 De doc. chr. 1.9.29 [21].

23 For this reason, Eric Gregory (Politics and the Order of Love, [27] p. 221) says that loving the neighbor in God entails protecting the neighbor from distortions of love that view the neighbor as existing for our ends. 
By framing the theodicy of On True Religion in terms of the problem of the One and the many alongside being and becoming, Augustine establishes that the true good of creation lies not in the individual but in the whole tapestry of creation. Therefore, the individual is not truly beautiful in itself but only as a part that contributes to the beauty of the whole. Since Augustine conceives of the whole in terms of the grand design of Providence, the good of the individual creature must be understood instrumentally, i.e., as fulfilling its role in the economy determined by Providence. Consequently, there can be no proper love of self or of neighbor that does not value them-or ourselves-as parts that contribute to the beauty of the whole. Since the goodness and the beauty of the individual lies in her instrumental role in the unfolding progress of the economy, what we love about the individual is her contribution in this moment in time to the completion of humanity's journey to the end of history. The primary relationship between individuals is one of cooperative and mutually beneficial use that contributes to the fulfillment of the divine design wherein our eudaimonia is attained. The many members of the one body, though used differently by God for different tasks, contribute to the healing of the whole body. ${ }^{24}$ Our love of God and of his Wisdom that is the ordering principle of the economy is necessarily prior to and the condition for our love of self and of neighbor. When we become partakers of the divine Wisdom through the gift of the Holy Spirit and are reformed according to the pattern revealed in Christ, then we are enabled to love both the supremely beautiful God and the beauty of the design of Providence. For in loving God and the Wisdom of his Providence we realize that our eudaimonia is attained by fulfilling our instrumental role in God's economy. In other words, love of self is grounded in an understanding that we are created to be used in conjunction with others as God's instruments in the plan of Providence. By understanding love of the neighbor as a contributing part of the beauty and harmony of the whole economy, the ontology of the One and the many allows Augustine to think of the instrumentality inherent to the love of neighbor as a necessary consequence of our love of God and the design of Providence. Because we also view ourselves as parts of the whole, we see ourselves as creatures God fashioned to be used in service of the same neighbor whom we use. The holy use of the neighbor is not a form of exploitation; rather it carries an implicit reciprocal commitment to each other for the sake of fulfilling our respective roles in the economy.

O'Donovan sees in Augustine's diminished use of $u$ ti over time evidence of his discomfort with its problematic implications ([22], p. 385). Even granting his shift away from $u t i$, it is clear that Augustine does not abandon the language of mutual instrumentality of self and neighbor expressed in the image of traveling companions (peregrini) assisting each other toward a shared eschatological homeland (ad patriam) where their citizenship lies (de doc. chr. 1.10.10). ${ }^{25}$ In Confessions, he refers to the human hearers of his confession as the companions in his joy and fellow pilgrims (mecum peregrinorum) whom, Augustine says, he has been ordered to serve if he wishes to abide with God and share in his life (conf. 10.4.6). The same image appears in his description of the mutual love of husband and wife, "God did not create [man and woman] as strangers but made them from one and the same flesh, indicating the strength of the union between them. They were destined to be joined to one another side by side as they walk together looking toward the goal of their journey," [40] (De bono conjugali 1.1). In his Homilies on the First Epistle of John, he intensifies the metaphor to depict the mutual dependence of traveling companions who support each other in their shared weakness, "You find a Christian, a citizen of Jerusalem...you find in the way a struggling pilgrim. Attach yourself to that one. Run with that one for indeed you are this one." ${ }^{26}$ Here mutual love, does not, pace Arendt, eliminate the original organic interdependence of people in the earthly city; rather the weakness of pilgrims' nature that results

24 De doc. chr. 1.16 .15 [21].

25 Although in the fifth stage of ascent during the journey to God the light of God is unbearably brilliant because of the corruption of the soul, the purification that allows the soul to grow in its capacity to apprehend God's light is the love of neighbor and enemy (de doc. chr. 2.7.11 [21]).

26 Tractatus I epistolam Joannis 10.2: Invenisti christianum; invenisti civem hierusalem; invenisti civem angelorum; invenisti in via suspirantem peregrinum. Adiunge te illi. Comes tuus est. Curre cum illo si tamen et tu hoc es. [41] 
from sin creates a necessary interdependence if either party is to reach the heavenly fatherland. ${ }^{27}$ Pace Adams, Augustine's view of the instrumental relationship between husband and wife and between Christian friends is not, as Adams suggests, mere valuing of the other the way one values the mobility a car provides ([30], pp. 186-87). For the shared telos of sisters and brothers in Christ gives their instrumental relationship a gravity that is infinitely greater than the instrumentality of an automobile. No mutuality exists between car and driver; the destination to which the car transports the driver is a good only for the driver. By contrast, the mutual longing for their shared destination and the recognition of the mutual dependence of the spiritual traveling companions creates a bond of love between them - a bond entirely conditioned by their mutual love of God and at the same time carrying a profound appreciation and gratitude for each other. Perhaps no greater instance of the mutuality of usus-charity can be found in Augustine than in his recollection in Confessions of his relationship with his mother Monica. Not only do her prayers contribute to his salvation, but as "a paradigm of unlearned wisdom acquired by grace" she teaches Augustine by her life a path to God other than through Platonic dialectic ([42], pp. 152-53). Monica too undergoes spiritual maturation. At the same time that her dogged loved of Augustine leads to his baptism, Monica herself journeys from simplistic piety mingled with superstition to the beatific vision at Ostia.

Yet $\mathrm{O}^{\prime}$ Donovan is concerned that the eschatological pilgrimage motif only reinforces the sense that the love of neighbor is a form of instrumentality "in which the object of use is assumed merely temporally and without commitment...[thus] 'use' of the world is sharply opposed to loving it." ([22], p. 393). On the contrary, however, this mutual instrumentality characteristic of the saints' relationships during their journey through the saeculum is not eliminated at the resurrection but transformed. Although the saints are no longer dependent upon one another for support and aid during the trials and hardships that characterize the earthly journey, their mutual love remains an important component of eschatological blessedness. Based on Augustine's depiction of the beatific vision in the penultimate chapter of City of God (22.29), the instrumental relation between the saints is perfected eschatologically when they receive the beatific vision by seeing God in the glorified bodies of the saints. Then use and enjoyment, instrumentality and eudaimonia are united. For then the saint shall enjoy God in her neighbor and the neighbor shall enjoy God in her. This is perfect instrumentality: when the indwelling God uses the saint to mediate his presence to the neighbor. Uti and frui are perfectly synthesized when self and neighbor are united in the saints' love of the one God through communion with the many saints who are neighbors in the Heavenly City.

Such a view of mutuality places Augustine's view of love strongly within a Platonic tradition and yet goes beyond Plato by extending the instrumental relationship eschatologically. While neither Plato's moderate utility-love of Alcibiades nor Augustine's instrumental love of neighbor constitute loving the other for his own sake, which Vlastos defines as true love, neither do their views of love lack the mutuality or reciprocity proper to Aristotle's ideal of friendship. For Augustine, the one love of God poured into the heart of the saints orders both love of neighbor and of self toward the one good thereby creating a true mutuality that neither privileges one over the other nor promotes an egoist virtue ethic. Even as Augustine's instrumental view of the love of neighbor sees the other person as a traveling companion whom one must aid and upon whose aid she likewise must depend on the journey to their heavenly destination, so too for Plato the philosopher's life of contemplative ascent is dependent upon the presence of the interlocutor. Within the Skeptic tradition of Platonism, the philosopher-the ideal lover-of the Symposium never fully possesses wisdom but always seeks it, ever ascending to the Beautiful through contemplation. The seeking, however, is not a Cartesian withdrawal from society into the privacy of one's study. Although Socrates at times in the Symposium is depicted as standing alone lost in his private thoughts, the form of discourse by which he ascends-if

27 Christian "mutual love" (diligere invicem) breaks the interdependence intrinsic to human relations created by their particular shared circumstances and replaces it with an artificial mutuality that is determined entirely by the external imperative (i.e., Christ's command) and the indirect character of Christian love (i.e., conditioned by the love of God) ([29], pp. 42, 108). 
the Symposium is read canonically within the Platonic corpus-is dialectic. Socrates, who is wise precisely because he is cognizant of his own ignorance, does not already possess knowledge but seeks it through dialectic; the series of questions he poses enables, not only his interlocutors, but himself also to recollect the truth, separating the merely apparent from the real. Even as Augustine says that God allows heresy to trouble the Church because the theological errors of the heretics challenge the catholic Christian to clarify her understanding of orthodoxy (vera rel. 6.10), the philosopher uses the errant opinions of his interlocutors to come to a clearer, though never ultimately definitive, understanding of the truth. The philosopher and his conversation companions ascend together and their souls are made better-though not to equal degrees—-by the broken lights of truth they discover together. In Plato's eschatology, however, the mutuality of teacher and interlocutor is not continued when souls have managed to escape their cycles of embodiment. There is no sense that the souls' existence in the intelligible heavens constitutes a community of seekers who need each other to mediate the knowledge of the True and Beautiful.

\section{Conclusions: Platonic Love Reconsidered}

Plato and Augustine's accounts of love in the Symposium and De doctrina christiana respectively raise a similar fundamental problem. Since the philosopher's loves are ordered according to the hierarchy of being-loving what is more real and more truly beautiful greater than what is less real-, the Platonist faces a conundrum: How can philosophers who love the perfect goodness and beauty of the Form of Forms genuinely love imperfect beings and not look on them and their imperfections with disdain ${ }^{28}$ For Christians, the Platonist's quandary takes the form: How does one's love of neighbor differ from the love of God such that God is not loved as simply one being among many or such that one's love for the creature is not on par with one's love for God and thus becomes idolatry? The Augustinian distinction between types of love-fruitio and usus-which preserves the Creator-creature distinction moves in a similar direction to Dominic Scott's distinction between Platonic है $\varrho \omega \sigma$, which is an "intense obsession" with eternal Ideas in their perfection, and a moderate or lesser love for imperfect mortals ${ }^{29}$, which preserves the distinction between the philosopher's first love and secondary loves.

True, Plato's Socrates does not love the imperfect individuals or human beings as a class with the same devotion that he does the Beautiful. Lesser beings are not the gravitational center of his life. His first love, nevertheless, is the cause of a genuine desire for the eudaimonia of his fellow citizens. He never ceases to be a citizen actively seeking the good of the whole polis. In whatever way Socrates' devotion to contemplation caused him to give up Alcibiades as an erōmenos (i.e., young male lover and protégé) and even, as Alcibiades declares (Symp. 216e), to look upon him with contempt ([43], p. 33) ${ }^{30}$. Socrates is not indifferent to his interlocutors or their well-being. Having been persuaded by Diotima to pursue the contemplative life, Socrates' conversion to philosophy leads him to embark upon a quasi-evangelistic enterprise of converting others to the love of the Beautiful. Thus Socrates honors the god "E $\varrho \omega \sigma$ not by giving encomia like those of his immoderate dinner companions, but through his philosophical vocation to better people's souls by initiating them in the nobility of philosophical हैow (Symp. 217a): "And once persuaded, I try to persuade others too that human nature can find no better workmate for acquiring this than love" (212b). Yet given the correspondence between love and ontological rank, Socrates loves individual souls less than he does rational souls as a class of beings, which is ontologically superior to imperfect instantiations of the class ([43], p. 35). If Socrates is at

28 Vlastos ("The Individual as an Object of Love in Plato," 156) [19] puts the point most starkly, "As objects of Platonic love all these [e.g., impersonal objects from political institutions to scientific theories and "best of all, the Idea of Beauty itself"] are not only as good as persons, but distinctly better."

29 Symp. 216d-e. See ([43], p. 29).

30 It is also doubtful whether Alcibiades' judgment should be taken at face value. Does Socrates treat him with contempt or does Alcibiades, who is accustomed to getting his way, simply feel that he is treated contemptuously because Socrates is not seduced by his physical beauty and charm? 
all contemptuous of Alcibiades and the litterati at Agathon's drinking party, it is not contempt for Alcibiades and friends qua human beings—rational souls—but contempt for them qua self-important, unphilosophical hedonists. Because his love is conditioned by his ascending knowledge of the Beautiful, Socrates is genuinely and moderately concerned about Alcibiades, Agathon, and Aristophanes qua rational souls that are in need of betterment. Socrates' moderate love for these interlocutors-as well as for the more hostile and dangerous, such as Thrasymachus whom Socrates makes gentle (Rep. 354b)—satisfies the guiding definition of justice in Republic ([44], 335b-e). The philosopher, who has ascended from a love of individuals to a love of rational souls, cares for his interlocutors with a just and moderate love because of the beauty inherent in rational souls and, therefore, their potential for becoming actually beautiful by active participation in virtue.

Augustine's ontology of the One and the many not only provides a unity of desire that overcomes the distention of disordered desires but also establishes the logic of creaturely instrumentality foundational to the uti-frui account of Christian love. The Christian's one love of God and, by extension, the economy of salvation conditions her love of the many creaturely goods, most of all her neighbor and herself. She loves them because God loves them and she loves them as parts within the divine economy, each of which, knowingly or otherwise, contributes in the unfolding of the economy in history. To love one's neighbor and oneself within the context of salvation history is, for Augustine, to recognize the mutual dependence of self and neighbor. It allows the Christian to love even her enemy as a gift that God uses for her sanctification, training her in God-like patience and forbearance. But it also allows her to imagine that God is using her within the unfolding economy to bring an enemy of Christ, such as Saul of Tarsus or even the young Augustine himself, into the Church. While Plato and Augustine's eudaimonism leads them to share a vocational desire for the betterment of others, it is Augustine's understanding of salvation history and individuals' roles in history, which is completely absent from Plato's thought, that conjures a macro view of love and mutuality that surpasses Plato's narrower view of redemptive dialectic between interlocutors. Augustine's account, however, begs a yet deeper question: How does the Christian's knowledge of God as the One, the Principium, provide the unity in her experience of the world such that she is able to love the neighbor in her particularity within the schema of God's economy? Since, as Augustine concedes, "there is no human being who can grasp the whole range of time and its successive ages," (vera rel. 22.43) how can rational creatures located in the middle of history gain a vision of the big picture that allows them to use and love their neighbors appropriately? Only if the Christian's intellect apprehends God's creative artistry by surveying salvation history as a whole is she able to grasp the true beauty of individuals as parts of the whole, i.e., in the particular role they play in the plan of Providence. Such a vision is at most an eschatological possibility. Indeed, the saint's love of neighbor in God will be perfected only eschatologically precisely because only then will the saint come to a perfect vision of God's economy and the roles of other saints within salvation history. There is not space in this essay to give a developed answer to the problem of loving the part without seeing the whole. Yet Augustine's logic gestures towards a path down which we might seek an answer. For Augustine, the closest the Christian can come in this life to seeing the whole and the role that each part plays within the whole is through memory and the discipline of Christian confession. For confession holds the whole of one's life to that point before one's eyes allowing the Christian-like Augustine recollecting the good use God made of an unnamed friend, a Milanese bishop, and his mother to bring him back to the Church-to see the many players, oneself included, in the unfolding subplots of the divine drama. To be sure, such a view is necessarily retrospective while the love of neighbor is active in the short-sighted present. Yet, the Augustinian notions of Providence and confession create a historical consciousness that situates the self and others within the economy and thus allows the Christian daily to imagine herself in relationship with others-a relationship of mutual use and benefit—on the journey to their heavenly end.

Conflicts of Interest: The author declares no conflict of interest. 


\section{References}

1. Santas, Gerasimos. "The Form of the Good in Plato's Republic." In Plato 1: Metaphysics and Epistemology. Edited by Gail Fine. Oxford: Oxford University Press, 1999, pp. 247-74.

2. Rosen, Stanley. Plato's Republic: A Study. New Haven and London: Yale University Press, 2005, p. 360.

3. Plato. Republic. Translated by Paul Shorey. Cambridge: Harvard University Press, 1930.

4. Plato. Euthyphro. Translated by Harold North Fowler. Cambridge: Harvard University Press, 1914.

5. Plato. Meno. Translated by Harold North Fowler. Cambridge: Harvard University Press, 1914.

6. Irwin, Terence H. "The Theory of Forms." In Plato 1, Metaphysics and Epistemology. Edited by Gail Fine. Oxford: Oxford University Press, 1999, pp. 143-70.

7. Altman, William H. F. Plato the Teacher: The Crisis of the Republic. Lanham: Lexington Books, 2012, p. 152.

8. Plato. Symposium. Translated by Walter Rangeley Maitland Lamb. Cambridge: Harvard University Press, 1925.

9. Brown, Peter. Augustine of Hippo: A Biography. Berkeley: University of California Press, 1967.

10. O'Donnell, James J. Augustine Confessions, Vol. 2: Commentary Books 1-7. Oxford: Clarendon Press, 1992.

11. Courcelle, Pierre. "Plotin et saint Ambroise." Revue de philosophie, de Litterature et d'Histoire Anciennes 76 (1950): 29-56.

12. Courcelle, Pierre. Recherches sur les Confessions de saint Augustin, 2nd ed. Paris: Éditions E. De Boccard, 1968.

13. Hadot, Pierre. "Platon et Plotin dans trois sermons de saint Ambroise." Revue des Études Latines 34 (1956): 202-20.

14. Colish, Marcia. Ambrose's Patriarchs: Ethics for the Common Man. Notre Dame: University of Notre Dame Press, 2005.

15. Smith, J. Warren. Christian Grace and Pagan Virtue: The Theological Foundation of Ambrose's Ethics. Oxford: Oxford University Press, 2011.

16. Rist, John. Augustine: Ancient Thought Baptized. Cambridge: Cambridge University Press, 1994.

17. O'Meara, Dominic J. Platonopolis: Platonic Political Philosophy in Late Antiquity. Oxford: Oxford University Press, 2005.

18. Bussanich, John. "Plotinus's Metaphysics of the One." In The Cambridge Companion to Plotinus. Cambridge: Cambridge University Press, 1996, pp. 38-65.

19. Vlastos, Gregory. "The Individual as an Object of Love in Plato." In Plato 2: Ethics, Politics, Religion, and the Soul. Edited by Gail Fine. Oxford: Oxford University Press, 1999, pp. 137-63.

20. Plato. Lysis. Translated by Walter Rangeley Maitland Lamb. Cambridge: Harvard University Press, 1925.

21. Augustine. De doctrina christiana. Translated by R. P. H. Green. Oxford: Oxford University Press, 1997.

22. O'Donovan, Oliver. "Usus and Fruitio in Augustine, De Doctrina Christiana I." The Journal of Theological Studies 33 (1982): 361-97. [CrossRef]

23. Nygren, Anders. Agape and Eros. Part II.1. Translated by P. Watson. London: Society for Promoting Christian Knowledge, 1939.

24. Barrett, Lee C. Eros and Self-Emptying: The Intersections of Augustine and Kierkegaard. Grand Rapids: William B. Eerdmans, 2013.

25. Gonwa, Janna. “Eros, Agape, and Neighbor-Love as Ontological Gift." Toronto Journal of Theology 31 (2015): 84-93. [CrossRef]

26. Canning, Raymond. The Unity of Love for God and Neighbor in St. Augustine. Leuven: Augustinian Historical Institute, 1983.

27. Gregory, Eric. Politics and the Order of Love: An Augustinian Ethic of Democratic Citizenship. Chicago and London: University of Chicago Press, 2008.

28. Herdt, Jennifer A. "Empathy beyond the In-Group: Stoic Universalism and Augustinian Neighbor-Love." Philosophy, Theology, and the Sciences 2 (2015): 77-81. [CrossRef]

29. Arendt, Hannah. Love and Saint Augustine. Translated by Joanna Vecchiarelli Scott and Judith Chelius Stark. Chicago: University of Chicago Press, 1996.

30. Adams, Robert. Finite and Infinite Goods: A Framework for Ethics. Oxford: Oxford University Press, 2002.

31. O'Donovan, Oliver. The Problem of Self-Love in St. Augustine. New Haven: Yale University Press, 1980. reprinted by Wipf and Stock, 2006. 
32. Augustine. De vera religione. On Christian Belief. Edited by Boniface Ramsey. Translated by Edmund Hill. Hyde Park: New City Press, 2005.

33. Wetzel, James. Augustine and the Limits of Virtue. Cambridge: Cambridge University Press, 1992.

34. BeDuhn, Jason David. Augustine's Manichaean Dilemma, I: Conversion and Apostasy, 373-388 C.E. Philadelphia: University of Pennsylvania Press, 2010.

35. Burleigh, John H. S., ed. Augustine: Earlier Writings. Philadelphia: Westminster Press, 1953.

36. Dostoevsky, Fyodor. The Brothers Karamazov. Translated by Richard Pevear and Larissa Volokhonsky. New York: Vintage Classics, 1991.

37. Hannam, Walter A. “Ad illud ubi permanendum est: The Metaphysics of St. Augustine's usus-fruitio Distinction in Relation to Love of Neighbor, De doctrina christiana, I." Studia Patristica 8 (2001): 169-73.

38. Burnaby, John. Amor Dei: A Study of the Religion of St. Augustine. Eugene: Wipf \& Stock Publishers, 2007.

39. Baer, Helmut David. "The Fruit of Charity: Using the Neighbor in De doctrina Christiana." Journal of Religious Ethics 24 (1996): 47-64.

40. Augustine. De bono conjugali. Treatises on Marriage and Other Subjects. Translated by Charles T. Wilcox. Washington: Catholic University Press, 1955.

41. Augustine. Tractatus in Epistolam Joannis ad Parthos. Homilies on the First Epistle of John. Translated by Boniface Ramsey. Hyde Park: New City Press, 2008.

42. Kenney, John Peter. Contemplation and Classical Christianity: A Study in Augustine. Oxford: Oxford University Press, 2013.

43. Scott, Dominic. "Socrates and Alcibiades in 'Symposium'." Hermathena 168 (2000): 25-37.

44. Augustine. De civitate dei. Translated by George E. McCracken. Cambridge: Harvard University Press, 1957.

(C) 2016 by the author; licensee MDPI, Basel, Switzerland. This article is an open access article distributed under the terms and conditions of the Creative Commons Attribution (CC-BY) license (http:/ / creativecommons.org/licenses/by/4.0/). 